\title{
Young ethnic German late resettlers from Poland - "(quasi)-forced nature of migration" vs. success of integration
}

\author{
Magdalena Tomaszewska \\ magdatom@amu.edu.pl
}

\begin{abstract}
"(Late) resettlers", or to put it in simple terms, people of German ancestry who came to Germany from Eastern Europe after World War II, constitute a peculiar case within the spectrum of German migration. On one hand, they are distinct from foreigners, on the other hand, despite having German citizenship, they stand out from the native German population. L. Wilkiewicz refers to this category as "quasi-forced resettlers". The forced nature of the young resettlers migration may then be seen as doubly strengthened by the fact that they had no impact on their parents decision to leave the country. They were, in a sort of way, uprooted from their original environment and planted into a new, alien one. Having accepted German citizenship and having been attributed the purpose of "living as Germans among Germans", the resettlers were expected to show a higher degree of integration with local society than "ordinary" migrants. In this study, I shall confine myself to a few selected aspects affecting the success of integration. Presented below are some of the memories that the young resettlers have of the moment of their "(quasi)-forced" migration, of their early days in Germany, of Poland as the country of their childhood, of the reasons for departure as given by their parents, and of the main factors - apart from those personality-related such as intelligence that contributed to their successful integration.
\end{abstract}

Key words: (late) resettlers (in Germany), integration, migration, young migrants, GermanPolish relations, German-Polish migration, bilingual socialisation, second generation 
"(Late) resettlers"1, or to put it in simple terms, people of German ancestry who came to Germany from Eastern Europe after World War II, constitute a peculiar case within the spectrum of German migration (Tomaszewska 2006a, p. 189-191; Tomaszewska 2006b, p. 55-58). On the one hand, they are distinct from foreigners, on the other hand, despite having German citizenship, they stand out from the native German population (Graudenz, Römhil 1996, p. 29). L. Wilkiewicz refers to this category as "quasi-forced resettlers" (Wilkiewicz 1989, p. 9). In the case of the late resettlers of the 1980s and 1990s, we are definitely dealing with a forced kind of migration, comparable in this respect to earlier waves of expulsion or exodus (Lüttinger 1989, p. 57). The forced nature of young resettlers migration may then be seen as doubly strengthened by the fact that they had no impact on their parents decision to leave the country. They were, in a sort of way, uprooted from their original environment and planted into a new, alien one (Tomaszewska 2006d, p. 40-45). Having accepted German citizenship and having been attributed the purpose of "living as Germans among Germans" (Meister 1997, p. 32), the resettlers were expected to show a higher degree of integration with local society than "ordinary" migrants (Meister 1997, p. 32). By becoming German citizens they were rapidly incorporated, at least officially, into German society. After a five-year stay in Germany resettlers are deemed to be fully integrated and classified as Germans for statistical purposes. Hence, data concerning resettlers refers mostly to initial periods following their registration in Germany (Kunschner 2000, p. 25-26). The fact is, however, that late resettlers, in particular the younger ones with a strong Polish background, often arrived at their new homeland with no or insufficient knowledge of German. Their starting position was, however, incomparably better than that of other migrant groups, if only by the fact that they were given German passports, unlimited right of residence, transitional flats, access to social welfare, and other benefits such as language and vocational courses, retraining, etc. (Pallaske 2002, p. 54). This privileged position, combined with the commonly shared opinion that late resettlers' motives were strictly economic (Volkswagendeutsche) and their German origin used instrumentally, that they were the cause of the shortage of jobs and housing and a burden to the State social system, raised criticism and the adverse approach of German society

\footnotetext{
${ }^{1}$ Ch. Pallaske suggests the following division: up to 1945 - "Flüchtlinge": fugitives, refugees; later, up to 1949 - "Vertriebene": exiles; since 1950 - "Aussiedler": resettlers; and from 1993 - "Spätaussiedler": late resettlers (Pallaske 2002). In the Polish literature the term "late resettlers" has been adopted as referring to persons who left the country in the 80 s and the 90 s of the 20th century. Such understanding of this notion has been adopted in this text.
} 
(Kunschner 2000, p. 187-188), especially in the period of intensive migration inflow (1980/81-1990) (Pallaske 2002, p. 62). Fully aware of the discrepancy between the official image and the actual state of affairs, organisations and institutions providing assistance to resettlers have emphasised that integration of late resettlers requires in principle the same actions as those taken towards the other groups of migrants (Uilhlein 2002, p. 16). Integration is a bilateral process (Dietz 1997, p. 38) that involves "political, economic, social, cultural, and possibly religious inclusion or incorporation (Eingliederung) [in this case: into the German society - note by M. Tomaszewska] while protecting and preserving values brought by migrants' from their country of origin" (Dietz 1997, p. 55).

The late resettlers that have been interviewed for the purpose of this study using the method of biographical narrative interview (Tomaszewska 2006a, p. 191-193) (10 young people who at the time of their arrival to Germany, that is between 1984 and 1990, were between 5 and 14 years of age) are now high school students, that is to say people who seem to prove by their social status to have been successfully integrated into the German society and recovered from the migration-induced breakthrough. According to B. Dietz, "if young resettlers perceive their double cultural background as a chance, the sense of »not belonging to Germans«, which impedes the process of integration, is more likely to be overcome“ (Dietz 1997, p. 79).

In this study, I will confine myself to a few selected aspects affecting the success of integration. Presented below are some of the memories that the young resettlers have of the moment of their "(quasi)-forced" migration, of their early days in Germany, of Poland as the country of their childhood, of the reasons for departure as given by their parents, and of the main factors - apart from those personality-related such as intelligence - that contributed to their successful integration. The study makes no claim to be statistically representative. All the interviews have been transcribed without recourse to "literary technique". The interviewees' parents all had secondary (11) or high education (8), except for one mother with a basic education level. For the sake of anonymity, the interviewees are designated by their main degree course, e.g., Theatrologist, with the age at arrival in Germany given in brackets and - for readers with more profound interest in the subject - the type of national identity.

\section{Poland - the land of my childhood}

The interviewees stress that they do not remember much as they were too young at the time of their departure: “Impressions from Poland... Now, I don't think I have any special 
impressions. I had not been at Polish school that long, it was like two and a half years, and I think it was just an ordinary childhood. A regular family, like any other in Poland of the eighties. I had many friends, you know, boys and girls" (Theatrologist ${ }^{2}$, Neutral European ${ }^{3}$, B. $\left.1,9^{4}\right)$.

While their parents were trying to find a way to leave Poland for good, they "were living a normal life", because "as a child you do not notice many things": "Me, I lived a normal life - I stayed at my grandmother's, I used to go to the cinema a lot, I enjoyed my life down there. OK, there we had no sweets, but that was kind of cool, too - I could live without them, but perhaps it's about the way you see things as a child, you know, kinda more positive than grown-ups do" (Historian, European Mischling, B.4, 9).

Basically, the only person to have only dismal memories of Poland is the Male Economist (B.10), whose strongly pro-German parents created an image of Germany by contrasting that of Poland, continually stressing the lower status of the latter. The first thing the Male Economist (B.10) recalls about Poland is a memory of a school Christmas party with Santa Claus giving out sweets to children. When he came back home, his mother made him throw the sweets in the dustbin, saying: "why eat this lousy stuff, you may have better gifts from your grandma in Germany".

The others express opinions based on their own experiences. The Biophysicist (B.3) recalls "stinky car fumes" and queues: "what I recall from Poland, are those cars and the odour they were leaving. When I was a child, I remember standing in queues, sometimes for hours, with my mum, It was like sitting in the sunshine and waiting for ages to buy... I don't know... something to eat or whatever [laughing]" (Biophysicist, Contextual European, B.3, $5)$.

1. A similar image of Poland is kept by the Historian (B.4). Before coming to stay permanently, he had spent a month with his family in Germany. This gave him yet another plane of comparison. If only for the "gloominess of Silesia" (where he came from), his view was certainly in favour of the "colourful Germany". Even today, standing in a line to get his lunch in a canteen brings back unpleasant past experiences from Polish shops. Poland, in his opinion, was also characterised by a limited flow of information: "I remember, I didn't

\footnotetext{
${ }^{2}$ Field of study.

${ }^{3}$ Type of national identification - as described in: Tomaszewska 2006a, p. 193-197; Tomaszewska 2006b, p. 5961; Tomaszewska 2006c, p. 51-55.

${ }^{4}$ Age at immigration.
} 
like those Schlangen [queues] back then in the communist days, but now in Mensa [canteen] I don't like it either. I often recall how we had to queue for things. I was 6 when my mum went to Germany with me for a month. Sure I loved it here, she'd got an invitation from a cousin of hers who lived down here in Bayreuth so we came to live with her for a month. Then came this bang in Russia, in Chernobyl, and there was so much panic in Germany. You must not sammeln [collect] mushrooms, children must not play out and so on. And in Poland, they knew nothing [laughing]. Oh, how I liked it here, the sun was shining, everything so colourful, while Silesia is so gloomy - I don't know if you've been to Silesia, but gloomy it is. And shops were full of products here [laughing] and then we came back to Silesia after a month, it was raining, it was bleak, I wasn't fond of it at all. I went to first and second class in Poland, then my parents decided to leave for Germany, my dad had deutsche Staatsangehörigkeit [German citizenship] through his dad, so we could have come here even earlier, but somehow we didn't” (Historian, European Mischling, B.4, 9).

The Female Economist (B.2) refers twice to her bad memories of a collectivist preelementary school she attended in Poland - where everybody had to do the same thing at the same time - contrasting it with a "more liberal" German school: "I hated going to that preelementary school. It always made me sick when I had to go there, I didn't want it, 'cause it was like we had to do something, like drawing or writing, then they made us go to a toilet all together at the same time, then all had to go to bed and I wanted to pee just when we were supposed to sleep. So what could I do? I told the teacher I wanted to pee: »No«, she said »the pee time is over«, so I peed in my pants, what else could I do? And my mum and dad went there and asked how was that possible, or something. That's why, I don't have any good memories of that school, no, none at all. They made you..., you know, you had to eat everything from your plate? I didn't like that food at all but I had to eat it no matter what. And then, when I came here to Germany, oh, it was all so cool - you could play, you could talk, a break was a break, you wanted to go to a toilet - no problem, go whenever you want. Well sure, first you need to tell somebody. Yeah, that's the point, everything here was kind of more... locker und lustig [nice and easy going] [laughing]" (Female Economist, Integral Mischling, B.2, 6).

Her other memories, however, not unlike the rest of the group, were basically simple, idyllic pictures of tomatoes in the grandma's garden, dad's motorbike, home-made sausage, a dog friend, family reunions, etc: "I have to tell you I don't remember that much! I can recall my dad had this motorbike called Komar [laughing] and kept on riding it, my grandma was 
busy farming and gardening. I also remember we had fresh chives and tomatoes from the garden and how I always liked eating them. In the beginning, my dad had a farm with chickens, pigs and sheep. Oh, yes. And we had a dog, a collie called Lassie. That's right, the dog kept looking after me all the time, ever since I was a little girl. Then we had to leave her, and she missed my dad so much that she died. I mean, because she was sick and old, but also because, you know. Funny, 'cause now when I see a big dog, I mean, I'm afraid of big dogs, which is strange, because I was brought up by a big dog [laughing], wasn't I? One more thing... I'm not sure if it belongs to childhood, but when my dad made those sausages of his, oh, I always ate them, they were yummy [laughing], Right. And I was..., 'cause you know my dad had this camping house in Poland, I mean a little hut in the countryside and we spent a lot of time there, we had barbecues, grills, even my brother stayed there when he came to visit us from Germany, you know. That's right, the dog was there, Lassie" (Female Economist, Integral Mischling, B.2, 6).

Among the things they missed after moving to Germany were Polish snowy winters: "There was always a lot of snow in Poland, and then when we first moved to Hagen, you know, there's actually no winter in Hagen. You've got a little bit of snow, then some slush and that's it. Then, we went to Poland and there was so much snow, I made snowmen and played in snow. That is something I missed a little, I remember my first winter here in Bayreuth, everybody else was cold, the folks from Peru and Spain were going like that [she is tucking her hands under her armpits], while I was only laughing: winter, snow, that's so nice so nice. This is one of the things I brought with me from Poland, I mean winter" (Female Economist, Integral Mischling, B.2, 6).

The confrontation with the German environment, which was not always friendly, brought back the positive memories of living in Poland. The first question they were usually asked was: Where are you from? Therefore, even today they are oversensitive and prejudiced to this question: “(...) it was so hard when we moved from one flat to another in Bayreuth. In Poland, we lived in a big housing estate - that was real life. You could see children playing in a sandpit, there were lots of people around. And here in Germany, it's so quiet. I met some kids of my own age, but they always went like: »I see, you're from Poland «. The first question was always: »Where are you from?«, that's why, I don't like this question so much”. (Historian, European Mischling, B.4, 9).

\section{"Quasi-forced" nature of migration}


Only two my interviewees, who left Poland at the age of 14 (Builder, B.5) and 13 (Mathematician, B.9), thus being the oldest of the group, were aware that they were leaving for good: "I knew it right away [that it was going to be permanent]. We had sold out everything [laughing], except the flat. Only after a year we came back to sell all that was left, including the car" (Builder, Uncertain Silesian, B.5, 14). My interlocutors had been told to keep this information secret. Officially, they were leaving for a month, for holidays, or to "visit an auntie" after having received an invitation from her: "One day, my mum took me aside and said: "what if we went to West Germany and stayed there? « At that time... no, I didn't think of any consequences, not at all. For me, it was like an adventure, you know, Abenteuer. I had no idea what it really meant for our future life, but I remember I liked the idea a lot. But my view at that time was not very - how to say it - critical. Of course, my parents told me not to tell anybody, you know, that it was Geheimnis [secret], and so on, but I did say goodbye to all my friends that were very close to me then. And then we left. So, it was to be a one-month stay only. Officially, we went to visit my mum's sister who had lived in Germany since the eighties, she left for West Germany during the Martial Law period. Come to think of it, I don't even know what formal basis we had. My mother's parents have... How do you say Staatsangehörigkeit, German... how to say it? (...). »Citizenship«, right! (...). So we have, we had German citizenship, that's why, my aunt could go to West Germany, and it was her that we visited then, but of course we were going with the aim of staying there permanently" (Male Economist, Uncertain European, B.9, 13).

Being open about one's intention to emigrate usually involved adverse consequences, including the loss of a job or flat. However, none of the families in question experienced this sort of repercussion. As a matter of fact, my interviewees are not very familiar with formal details behind their migration nor do they show a desire or need to study them any deeper or to learn more about their families' history: "My mum told me once that before I was born, in 1974 or 1975, one of my dad's friends wanted to move to Germany, too, and he just kept saying it openly. He submitted some sort of Antrag [application], you know, and the very next day he was out of his flat and out of his work. That's why my dad thought ten times before dropping a word about it, mum said it wouldn't be such a problem for him as he had deutsche Geburtsurkunde or something, I can't tell you genau [exactly] for I don't know about these things myself" (Female Economist, Integral Mischling, B.2, 6).

Most of the interviewees were not aware that they were "leaving for good". They did not even have a chance to say goodbye to their friends and family. It was only in Germany (or 
on the way) that their parents told them the truth. As they admit, they did not realise then what it really meant, but all of them were actually happy to go. They saw it as an adventure, wanted to experience something new. Moreover, "at that time it was cool to live in Germany". The Theatrologist (B.1) admits that he was proud of it, although in his further comments he's more critical, pointing out his Polish origins and the wrongly understood patriotism: "When I learnt about our going to Germany, and I learnt about it very late, at first I didn't know it was permanent, 'cause our plan was to go and visit our aunty. So, there were no big goodbyes, and only then, when I was here in Germany, did I find out that the plan was actually for a permanent stay. You see, my parents, they had planned it before but told me nothing to keep it secret and so that their parents didn't know 'cause it might have been a real shock for them, and a lot of trouble if other people knew. So the plan was to come here like were going for holidays. Now, I think it was not a big shock for me to learn that we were going to stay, 'cause then, at may age, it was kind of cool to go to Germany and stay there. I don't know, at first I was in close contact with my classmates and after a few months when we came to Poland again for my brother's first communion I visited my school and, you know, I think I was proud of living in Germany, sure I was, but then all the rest of my family was sad to learn that we were staying in Germany. Then again, a few months later my mum came here with my brother and all became clear and good" (Theatrologist, Neutral European, B.1, 9).

The interviewees do not refer to their departure from Poland as a "painful" experience. Basically, rather than feeling "uprooted", they mention being open to the "new". As a rule, they had no idea of what to expect and they cared more about sweets than the future. Older age at departure might possibly strengthen the sense of being "uprooted", but the Mathematician (B.9), who was then 13, says: 'No! Not at all! I didn't think too much about the future then. Generally, I accept things as they are. And especially at that time I thought more about sweets than any other consequences" (Mathematician, Uncertain European, B.9, $13)$.

By contrast, the Builder (B.5), who was then 14 and fully aware of the preparations being made to leave, felt happy to go, but also believed, while saying goodbye to his friends, that one day he would come back to Poland. Later, he also found it more difficult to switch to the German way of life: "I was 14 on my arrival in Germany. It was towards the end of the seventh Class, in 1989, as I said before. That year many Polish people left the country. I have to say I'd had a very good time in Poland, I had many friends and acquaintances. Actually, for me it was not a very good time to leave as I was 14 and I started dating some girls [laughing] 
and, you know, these contacts were like beginning - and just then I had to go away. Yeah, that was a bad point. But of course we had planned this departure to Germany for a year or so. Since 1988, that's right, my mum was then waiting for an invitation from some friends from Germany, or should I say a family from Westphalia. Then you had to apply for passports and all that stuff. It all took a year to settle, before we could finally leave Poland. Besides, my parents must have been thinking it over for a long time, although I - how to put it - I didn't notice, but for sure, they must have hesitated to take this step, because it's like a serious thing to do - they had lived in Poland much longer than me... and to change your home country just like that - well, it's not an easy decision to take, anyway. For me it was very simple, I didn't have to consider it at all, not for a single second, whether I wanted to go or not, because I was just happy to have this chance to see something new and, generally, happy to go to Germany. But on the other hand I was leaving a lot of friends behind, and thought to myself that one day I would come back to Poland" (Builder, Uncertain Silesian, B.5, 14).

The most dramatic description of a departure from Poland was that given by the Biophysicist (B.3) who was crying hard while leaving Poland (as a five-year old boy) and shouting out "Poland, I will come back, I love you!". Then, for several years he was sure he would return to Poland when he grew old. But in time he changed his mind, although he is not going to stay in Germany, either: "Then in that bus, when we were leaving for Germany, I was singing a tragic song: »Poland, I will came back, I love you!«, not that I want it any more. They didn't tell me we were leaving forever, but rather for a kind of holiday. They didn't want me to make scenes, you know. Only then, when we were sitting on the bus, I learn that we're staying there permanently and... well, I was a little sad" (Biophysicist, Contextual European, B.3, 5).

All the families had had contacts with Germany before - the interviewees' grandparents, brothers, sisters or parents had already lived there. Some of the fathers had worked in Germany on a seasonal basis. This caused many families to break up as "some husbands would never return to their wives": "he (my dad) wanted to bring my mum with him, but that was impossible, so he didn't want to go at all. My dad also told me that there were many, so many, who left their wives, I mean, they were able to come, so they did and started a new life here. Yeah. But that's one thing my dad didn't want to do, and then new opportunities came up" (Female Economist, Integral Mischling, B.2, 6). None of my interlocutors came from a divorced family, but I know of two resettler marriages which broke up after their arrival to Germany, the main reason being the wife's strongly manifested 
"Germanness", even though, paradoxically, she had no German roots (now she is married to a German). The husband, with actual German background, returned to Poland after the divorce and married a Pole. Their children stayed in Germany but are considering remigration. In the case of the Female Economist (B.2), her mother was opposed to permanent emigration, arguing that she didn't want to leave her family, her mother and father. She went for advice to the local priest who told her "a wife's place is by her husband, and your parents are well taken care of here": "I missed my dad very much and as soon as I knew that I was going to stay with him, I was so happy. My mum told me that one day I'd got sick, while dad had been away in Germany, and I'd had a fever and wanted to see my dad so much. I missed him a lot and the doctor said that there was only one way: »the kid has to be with his father«. But how to do it, then my dad said: »So, come around here« and I knew I was going to my dad and I was so happy. I was sleeping all the way on the bus, then I woke up and saw my dad and it made so happy, that's what I remember. Afterwards, everything was kind of..., anyway, I was not afraid, 'cause my parents were with me and there were new things around, me being always curious about the world, so it was cool for me." (Female Economist, Integral Mischling, B.2, 6).

As for the Theatrologist (B.1), it was him that left first with his father "to prepare everything" and only then, after they arranged for a place to live, they "brought mum and brother". Here is a part of his story: "First, I came to Germany with my dad, then after several months my mum and my brother joined us, when we got our own flat. Before that, we had lived with my dad's sister" (Theatrologist, Neutral European, B.1, 9).

The interviewees are not ashamed to admit that their parents' actual reasons for emigration were mostly of an economic nature, although their material status at that time was relatively good. Their aim was to achieve a broadly understood improvement of living conditions and ensure better futures for their children. As most of them had relatives in Germany, they also cited the desire to join their families among reasons for departure as well as making all possible efforts to settle down close to them after arrival. This was one of the reasons behind internal migrations that occurred, for instance, when the newcomers were assigned to a Bundesland different from the one where their German-based relatives lived: "For my parents the goal was to ensure a better life for us, some better alternatives. They simply thought that of the three of us, I mean they had three children, they could somehow help one, but for the other two they had no means, that's why they left. On top of that, my mum missed her sister a lot and wanted to be closer to her. There were also some other 
reasons that I don't want to talk about, anyway she wanted to move closer and that was the motivation for leaving" (Mathematician, Uncertain European, B.9, 13).

Political motives were mentioned by the Female Economist (B.2): "It is because of communism that my dad wanted to leave for Germany as there were more opportunities there and freedom. You could speak your mind openly" (Female Economist, Integral Mischling, B.2, 6). But even if the concept of "communism" was referred to, it was more in the context of everyday life thus relating to economic issues: "Oh yes, communism [laughing]. These were hard times, but if we knew everything would change so fast, I mean for the better, perhaps we wouldn't have left in the first place. We didn't have our own flat down there, so we lived with our grandparents, we had three and a half rooms and, I don't know, maybe it's because there were no perspectives in Poland. They did it for me, so that I could have a better life, go to school, have a chance to study. It was a better option for them, too. For example, now we can afford to go for holidays, not like in Poland, to go around Europe, see places. Now it's different but in the old days it was impossible“ (Sociologist, Contextual Mischling, B.7, 5).

The Builder (B.5) admits straight away that nobody was leaving for Germany at those times just because they considered themselves German: "For what reason? To go away from here and live a little better. We did quite well in Poland, you know. We had that Trabant [laughing], went for holiday every year, but it all kind of... the reason was to go away and do a little better. You can say that about all the Poles that were leaving the country then. Now I don't know - it's getting better and better in Poland. Take me, I like Poland as it is right now. I can't tell you for sure, but in the old days everybody was going away to improve their living and not because they identified themselves as Germans, or whatever. No, it was nothing like that" (Builder, Uncertain Silesian, B.5, 14).

Except for the Male Economist's (B.10) and the Lawyer's (B. 8) mothers, German roots were of strictly instrumental relevance: if there is a chance, why not use it, especially that it made a real change (the same aspect was also indicated by the Polish Teacher): "They were planning to emigrate already when I was born. Then came Martial Law and they had trouble leaving. Their thinking was more like ekonomisch [economic] - it was so hard here and they wanted to see things going better. And with no perspectives in Poland, they used this option with citizenship - deutsche Staatsangehörigkeit [German citizenship], why not take it? My grandma and grandpa were the only ones to speak German. My parents were born in 
Poland in the fifties, so they spoke Polish only - my mum speaks good Polish, o yeah her Polish is perfect" (Historian, European Mischling, B.4, 9).

The Lawyer (B.8) refers to his mother's desire to be reunited with her parents living in Germany as the main reason for departure. The Lawyer's grandfather fought on the German side during the World War II. After the war he returned to his house which was then on the Polish side of the border. His grandparents had been trying to obtain permission to leave for many years. They identified themselves as Germans living in Poland. They did not approve of their daughter's marriage to a Pole whose parents, as if to make it even worse, had migrated from the region of Lviv. They had a very good knowledge of Polish but never spoke it, even when visited by members of their son-in-law's family, who spoke no German. Never again did they set their foot on Polish soil, having finally moved to Germany: "My grandfather was at war and stayed here after the war - I don't know how it all happened that they stayed in Silesia, I mean, it used to be a German region. He met my grandma in Germany, in a place called Gross Neukirche, she was German, too. They got married and started their life together. But it was like... my grandparents, they always wanted to... I mean when this territory was taken by Poland and so they became like Germans living in Poland. They'd always wanted to come back to that place they met or move somewhere else in Germany. I mean, all the time they felt as Germans and wanted to live in Germany, and tried hard to leave Poland. The procedure was that you had to write a sort of application... to... I don't know to whom...I don't know about these things... and it was so that they didn't get a permission to go away and leave it all behind. Then after a while they stopped even trying 'cause they saw no chance for leaving for Germany where they'd always lived. And so they almost gave up this idea of leaving Poland since my mum met my dad who was Polish - he came from Chrzanów, near Opole, and his parents came from Lviv. Then after the war they arrived at Głogówek in the Opole region. Then my mum met my dad. She was German, born in Poland but, you know, her parents were German, her grandparents were German, her great grandparents were German. She met a Polish guy and it was so that [laughing] my grandparents strongly disapproved of her meeting a Pole. They had always wanted her to marry a Silesian with some sort of German roots, while he had no German roots at all" (Lawyer, Neutral Mischling, B.8, 8).

Three of my interlocutors (Lawyer, B.8; Male Economist, B.6; Male Economist, B.10) point out that the lands awarded to Poland after the World War II, where their ancestors lived, used to belong to Germany. The Male Economist (B.6) seems to become aware of this only 
during the interview: "Wait a minute... Yes! It used to be... Let me think.... My grandma who moved here, but then it was... of course it was in Germany then! They lived in Pyskowice or something like that. I don't know exactly. You'd have to ask my mum about it" (Male Economist, German Mischling, B.6, 5).

The interviewees do not know many details of how they received German citizenship and who awarded it to them and under what conditions. They only know that they had some German ancestors. The status of a resettler actually meant nothing to them. It was something natural, something they did not need to think about - "we got it [a passport] as regular Aussiedler": "as we had German ancestors from my father's line. His mother and her family were of German origins. I don't know exactly. That's why we got it, as regular Aussiedler, and that was it. It was all clear with our German descent. We received German citizenship and we could stay here" (Theatrologist, Neutral European, B.1, 9).

The Builder (B.5) is the only case where German roots were both in the mother's and the father's line of the family. With foreign ancestry on one side only, formalities became more complicated: "My mother had to stay here and run from one office to another to get the permission to leave. My father came to Germany in 1987, to Bayreuth, and we joined him in August 1988. He lived in a little room, and the problem was for my mother to get that permanent stay permit, for me it was kind of automatic through my father, but she had to struggle for it and it wasn't that easy 'cause her family didn't have any German documents or anything” (Builder, European Mischling, B.4, 9).

All the families under study applied for the resettler status while already in Germany ${ }^{5}$, thus falling into the category of illegal resettlers. This might be the reason why the parents concealed from their children the intention of permanent migration. They did not want to take the chance of being accidentally given away by them. Until the end of 1990s, 90 per cent of late resettlers crossed the Polish border on the basis of tourist visas and only after arrival in Germany applied to be awarded resettler status. Only since 1990, pursuant to Aussiedleraufnahmegesetz, a permission to resettle in German Republic has to be obtained in the country of origin.

\footnotetext{
${ }^{5}$ Until the end of the 90 s as many as $90 \%$ of the "late resettlers" emigrated with tourist visas and strived for "resettler" status only after having reached their destination. See: W. Grabe (2000), Górnoślascy "przesiedleńcy"; w Niemczech, [in:] A. Wolff-Powęska, E. Schulz (eds.), Być Polakiem w Niemczech, p. 236. Since July 1990, In accordance with Aussiedleraufnahmegesetz, permission from the German state for one's arrival must be attained in the country of origin.
} 
The Biophysicist's (B.3) family was given German citizenship only three years after arrival. The Biophysicist is the only one to use the phrase "we became Germans". This involved germanisation of names so as to facilitate their spelling and pronunciation in German (e.g., Smoczyk was changed into Smotschyk, Gołąb into Golab, etc.): "How did it happen that we became Germans? I have a German family, a part of our Family is in Germany and there is one aunt still living who has documents in German proving that she's half-German or full German. It was she that came to help us then, she talked with those officers, showed them those certificates and we were granted German citizenship - we are officially classified as Vertriebene [exiles]. All this paperwork took like three years or so, I was in my third class when we received German citizenship. Then we also had to change our name to make it easier for Germans to spell and, you know" (Biophysicist, Contextual Mischling, B.3, 5).

The Historian (B.4) points out the privileged status of resettlers in relation to other migrant groups in Germany. They were entitled to participate in language courses, occupy transitional flats, etc.: "And they have this system in Germany that they offer you those courses for I don't know how long [laughing] and basically you have to pay for them, but there are, how to call it, Massnahmen [funds], for people like my mother who hadn't worked for a long time and were offered to go to work again. [M. Tomaszewska: »And German courses, did she take them, too? «] $J a$ [yes], she did. If you were Aussiedler [resettler], it was kind of automatisch [automatic], obligatory, you know. Worse if you don't have German citizenship, then they don't give you those courses. It's a small Mangel [shortcoming] in Germany, but at the beginning they were only for deutsche Staatsangehörigheit [German citizenship]. Those courses weren't that long, maybe ten months, which is not very long" (Historian, European Mischling, B.4, 9).

Resettlers were supported not only by German state authorities, organisations, or their own families already living in Germany, but also by individual people who simply wanted to help "somebody from Poland": "So, my parents wanted to move here, my father came to Bayreuth in June, but he didn't go to a Heim [transitional flat for resettlers], instead our cousin brought him to some people who offered to take in somebody from Poland and help. They hosted my father for a couple of months and helped him with all the documents and stuff, you know, running around offices that takes up a lot of time. They helped him with all of that, so he can now settle these things by himself" (Historian, European Mischling, B.4, 9). The Biophysicist (B.3), on the other hand, notes that his family was supported by Arabs: 
"First we went to West Berlin and we spent like three months there. We stayed in a kind of, I don't know, a building by a hospital. There were some Americans there and other foreigners. My mother did some interpreting for me. We had no residence permit, but some Arabs gave us a hand. It was hard" (Biophysicist, Contextual European, B.3, 5).

The young resettlers do not recall many signs of discrimination and hostility from Germans, who sometimes even helped them. Their parents seemed to be more affected by this problem: "There, I went to a nursery school for the first time. Well, my German was not that good, actually I spoke like three words. I had little problems because of that - kids laughed at me. They beat me. I beat them, too. And my sister did. But the place we lived was actually cool - people were helping us when we had any problems" (Biophysicist, Contextual European, B.3, 5).

The interviewees' memories from the initial period of their stay in Germany focus mostly around sleeping in overcrowded rooms, "running around offices", document checkups, but also something that made up for all the inconveniences - shopping: "I remember, we were going on a big bus with all the others, and then we stayed in a sort of, they call it Lager [camp], funny name but that's how they called it, and it was where all the documents... and we also slept in those big Turnhallen [gyms] with Matrazen [mattresses], me and my mum on this Matraze. And I have to tell you it was so frightening beängstigend [frightening]. But I was that much afraid, 'cause I was with my mum and I knew I would go to my dad, for I missed my dad so much, and that's why I wasn't, you know. What I really loved right after we came to Germany was shopping [laughing], when we went shopping, there was so much choice - so many kinds of fruit and everything, and we were buying so much. I remember I loved bananas then, so one day I ate so many that I couldn't look at them afterwards, that's what my mum told me [laughing] - oh, how I loved them. Sounds funny when I recall these things, what it used to be like. Now, it's so normal, isn't it, you go to a shop and you have whatever you want? But then, they had everything here... Now, you've got everything in 
Poland, too, right? All them Reals [supermarkets], they have them now, haven't they" (Female Economist, Integral Mischling, B.2, 6).

The interviewees underline the contrast between Poland and Germany of the late 1980s. This made a huge impression upon them, stronger even than parting with friends or the need to learn the language: "It was still a huge contrast then. In the eighties, in 1989, it didn't look good with things like (...), I don't know, Süssigkeiten [sweets] or other stuff. This was a bigger shock than the fact you had to learn the language or that you couldn't see your friends so long, or... you know. But then I didn't think in those terms at all" (Mathematician, Uncertain European, B.9, 13).

In fact, my interlocutors did not feel very strongly about parting with their relatives, playmates or school friends. What mattered most for them at that time was the fact that they were with their parents, brothers and sisters and thus felt safe. Actually, only the Female Economist (B.2) talks about missing her grandmother and her stories about the good old days: "I've always had nice memories of my grandma. It was so that my mother had a tailor shop right next to our house. It was under reconstruction and she always had to work very hard. It was at the time when I was born and later on. She was always home, I could see her - that's important, isn't it - but I spent a lot of time with my grandma. We went walking, I remember, to the forest and further away. That's why, when we left for Germany, well, first when my dad was here I missed him a lot, then when we left I missed my grandma a lot. That's why, I often said I wanted to go to my grandma, you know. She sang songs to me, she told me how it used to be in the past when she had to work in the field, how she met my grandpa, you know. This was my childhood". (Female Economist, Integral Mischling, B.2, 6)

The beginnings were also marked by removals. Each of the interviewees changed his or her place of residence at least four times (usually more) before even graduating from secondary school. Exceptional in this pattern were the families of the Male Economist (B.6) and Female Economist (B.7) whose removals were all within the city of Bayreuth. The migrations were often driven by the wish to live closer to a family that had already settled in Germany. This, as already mentioned, was not always possible at first because of the centrally-managed assignment to particular Bundeslands.

Four of the interviewees (Female Economist, B.2; Builder, B.5; Lawyer, B.8; Mathematician, B.9) lived in transitional flats. The other ones (Sociologist, B.7; Male Economist, B.6; Male Economist, B.10) stayed with their families, or had arranged for a flat 
before coming to stay permanently. This was the case with the Historian, B.4 and the Theatrologist, B.1: "We lived among Germans, ganz normal [quite normal]. Quite a normal flat in the centre of the town. They don't even pay attention to you then... I don't even know if my parents, I mean if we would have preferred to live in a Polish community then. I don't know. I believe I wouldn't. Because I always seek contacts with other people. But don't take me wrong, I have nothing against Polish people or anything. Not at all [laughing]." (Theatrologist, Neutral European, B.1, 9).

Those who had to stay in transitional flats for resettlers complain about poor living conditions, especially that the housing standards they had had in Poland were generally better (e.g. three-room flat). This transition period was about two years long. Then they had enough savings to buy a flat and some years later, built a house. This pattern corresponds to results of comparative research on "Polish and Russian Germans" - conducted by B. Dietz (Dietz 1997) with respect to "Polish Germans": "And then we left, also [so] we got to... how d'you call it... Friedheim [literally: piece home] - that was the name, don't remember exactly, it was simply Aufenthaltsdecken für Aussiedler [accommodation for resettlers]. It was a very small village, where they gathered all the Poles and Russians, first to check their citizenship status. Then we were taken to Hannover for... Damn, I miss the vocabulary! We went to Hannover for three weeks to stay in a kind of... a hotel basically, but it was more like Irrenanstalt [mental asylum], it looked like an $18^{\text {th }}$ or $19^{\text {th }}$ century place, you know. We stayed there for the three weeks, walked round Hannover, but we didn't have many possibilities there, because we didn't speak the language, it was not long after... you know. I think it was an old Krankenhaus [hospital], really! We stayed there and nothing. Three weeks passed and we went back to that village and they told us we could stay and choose a Bundesland to live in. My sister lived in Nuremberg then, so we wanted to go to Bayern [Bavaria] and we were assigned there - first we couldn't move to Nuremberg, because they had no place for us there, so temporarily they sent us to a place called Deckendorf, $200 \mathrm{~km}$ away from Nuremberg in Niederbayern [Lower Bavaria]. So we went to that Deckendorf. Right away, when we were in this Friedheim, we sold our car to a Polish guy who was very nice though and let us use to get to Deckendorf and then he came to fetch it. There was so much luggage... and we had this trailer. He bought that trailer together with the car. So, we went to this place Deckendorf, it was all the same again, the same kind of a hotel, it was like..., one star, you know, no more, I tell you..., the room like the size of this one, 12 square metres, maybe, for five people! It looked really awful! Double-deck beds...You come into the room and you see like the beds in 
front of you, next to the wall, then two chairs and a table opposite the door. And that's it. When we first came in there, we went like »Oh gosh! We're sure to get nuts here«. That's why, you know... that's why I was very happy to get out of there to a hostel in Bamberg" (Mathematician, Uncertain European, B.9).

Generally speaking, coming to Germany was not a traumatic experience for my interviewees. They talk of a relatively easy adaptation to their new living conditions, a smooth transition: "As for switching to a new environment, first thing, you need to learn the language. Without the language you could do nothing I knew that well enough. I knew, I just had to learn the language. If I didn't... I don't know, for example, all the habits they have here, I didn't need to follow - they're not so different from ours, anyway. But there was no need to, if you didn't want to. What mattered was that I had to learn the language. This was important to me and sure I wanted to speak the language to live here, to communicate with people" (Builder, Uncertain Silesian, B.5, 14).

If they had any difficulties, now they appear to be so distant that they can hardly remember them. They stress that being very young helped them to adjust to the new conditions in a fast and effective way: "No, it wasn't. Sure it was difficult, Umstellung [switch-over] was difficult. And the language was of course hard at the beginning, and other subjects, but learning the language was automatic then. If you heard it at school every day and on TV all the time..." (Theatrologist, Neutral European, B.1, 9).

In addition, they were too young on their arrival at Germany to realise the consequences: "No! Not at all! I didn't think too much about the future then. Generally, I accept things as they are. And especially at that time I thought more about sweets than any other consequences" (Male Economist, Uncertain European, B.9, 13). In general, they are happy with their life in Germany. They do not ask themselves what their lives would be like in Poland. They do not plan to re-emigrate, although allow the possibility of moving to a different country: "No, it was not a shock. [M. Tomaszewska: »Do you think, it was a good decision for you? «] I'm not sure, you know. Maybe it was, maybe it wasn't. I'd say it was. I don't know what I would do in Poland now. Surely, I would have completed my studies long ago [laughing]. I don't know, you never know what would happen if you did something else because you didn't - and you'll never know, right? What would be better, what would be worse? No idea. [M. Tomaszewska:»Are you happy now? «] You mean like in general, as it is now? I am happy, sure. I have problems sometimes, you know, with this or that, but who doesn't? But in general - it's fine, you know" (Builder, Uncertain Silesian, B.5, 14). 
All of them stress the importance and necessity of integration, rejecting the idea of being confined within one's own migrant community: "And I think it's important that when you live abroad you need to integrate? It's not a good idea to stick to your own folks only. I know other people, I see how their life is progressing, and I can tell you they live only where other Poles live nearby to be in your own regions, if I can say so? They never tried to break through, move on in their life, you know what I mean. My parents did the right thing, as I see it, "cause they got integrated well here in Germany" (Lawyer, Neutral Mischling, B.8, 8).

My interlocutors say that they owe their successful inclusion into the German society primarily to themselves and their parents: "Eingliederung in Deutschland [inclusion in Germany] (...) My parents and myself, I think. My parents never told me... I mean, I could decide myself how I wanted to live. I had much freedom. Viel Freiheit [much freedom]. And I think that was the way I chose myself" (Theatrologist, Neutral European, B.1, 9).

\section{Conclusion}

The students under study were successfully included into German society, they managed to integrate effectively and recovered from the breakthrough that was triggered in their lives by their "quasi-forced" migration.

In the initial period of their stay in Germany, the young resettlers tended to reach a consensus in the "we-they" relationship and in the course of time, with their migration no longer perceived as a critical life experience, rejected an option of returning to their country of origin, their point of departure.

Sentences like: "Well, we came as regular Aussiedler" or "In my family I've always heard it said that we are Aussiedler" seem to show that the students, well educated as they are, have very little knowledge of what it really meant to have a resettler status, although the term itself was explicitly mentioned in their homes. This may prove that their families treated the subject superficially, without going into details or clarifying the historical background, thus marginalizing its meaning. Some of my interviewees did not know whether they were Aussiedler, or not. They replied by saying: "I don't know. I would have to ask my mother what we are" (e.g. the Economist, B.6, whose actual status I found out only by calling his mother). This may lead to an indirect conclusion that for part of the parents having the Aussiedler status was, and still is, a sensitive issue, otherwise they would have spoken of it openly and explained it to their children. The argument that they did not consider it necessary as being Aussiedler or not had been a matter of secondary importance to them, do not seem to 
be well grounded in the light of discussions I have had with the priest of the Polish community, a Polish teacher, who by the way is an Aussiedler, and people supporting late resettlers both at school and outside.

Most of the interviewees were immediately sent to German schools attended by a small proportion of foreign students or other resettlers. Being Polish was not an issue there, and - as they point out - other students did not define themselves as resettlers or Poles (although the latter happened more often, particularly at the beginning when their accent still betrayed them). The language was for them a medium of communication, but very often failed to play a significant role in stabilising their national identity (Meister 1997). Virtually all of the late resettlers under study have been and still are intertwined into the German youth or student culture, holding close interethnic contacts. According to D.M. Meister, the young late resettlers preference for multicultural communities is driven by their aim to be separated from the majority and social orientation towards what is defined as minority. D.M. Meister, however, focused in her studies on resettlers in their initial period of stay in Germany. Therefore, her conclusions seem to be right only with respect to people who have not lived in Germany for long. Indeed, this category of resettlers tends to feel more akin to other immigrants, who share the same social status and the same kind of problems. This is, as if to say, a substitute contact chosen because of limited knowledge of German and consequent problems in communication. Later on, however, with language skills improving, young people begin to integrate more with the local community and the need to meet representatives of other cultures ceases to have the significance suggested by D.M. Meister.

With nationality not having any relevance on the social or structural level, there was also no impact on the self-identification level. In other words, the social environment is free of any national contexts. This has certainly influenced the resettlers national identification. For example, $\mathrm{X}$ 's national identification is manifested by referring to himself as somebody coming from Poland who was then legally incorporated into the system of German society and who feels attached, also socially, to Germans (Meister 1997, p. 219). X lives in the Present (in the sense that he does not think much about the Past), where he perceives himself, and is perceived by his peers, as a student. He places his Future in the frameworks of the German social environment. This form of assimilation does not exhibit features of "rebel reaction" (Meister 1997, p. 219), i.e. a purposeful rejection of the culture of the country of origin, as defined in the marginalisation concept. It is more about distancing oneself from the idea of living in Poland. Poland becomes a holiday destination not considered as a possible 
place of permanent stay as this would imply abandoning the current life style which cannot be achieved in Poland. Therefore, the young late resettlers that I have interviewed are not oriented towards their country of origin. One possible explanation is that their social environment has been and still is mostly German-speaking and their personal relationships both at school and otherwise (leisure time) are not established by the community of origin (Tomaszewska 2006c, p. 57-58). In practice, the interviewees have had no contacts with any Polish community or resettler support organisations.

The young late resettlers live between and with the two cultures, regarding both of them as their own (Kłoskowska 1996, p. 162). They do not have to prove their loyalty to either of them (Tomaszewska 2006d, p. 42). One might say, they are "liaisons between two worlds" (Mecheril 1997). Polish home and German friends and school, this is the reality they live in. Although they are sometimes unable to differentiate between Polishness and Germanness, between what is typical for both and what is unique, and although they often do not know whether they have been brought up the Polish or the German way, they enjoy their cultural flexibility and do not worry about their selective knowledge or segmental acquisition of either culture. Customs, traditions, religious practices, as originating from home, are mostly taken from the Polish culture. German traditions, even if known, are not followed. The "high culture", however, is built on the German culture, as originating from school. Young resettlers, even though Polish popular culture is more familiar to them than Polish high culture, admit they do not know how their Polish peers' lives appear, what kind of music they listen to, what kind of movies they watch. The culture of every day life, every day functioning (shops, offices), and lifestyle (youth), is also more of German origin. A home with Polish traditions can therefore be figuratively described as a Polish island on a German sea. The best illustration of this is the late resettlers' language. On one hand, Hochdeutsch learnt at German schools, on the other hand, a slang used instead of literary Polish, reflecting their parents' manner of speaking. The favourable experiences related to migration in combination with a general global tendency enhance their open approach towards mobility and other cultures.

It may be noted in conclusion that while the parents, lost between the public and private, declared and manifested identity (Schmidt 2003, p. 99), were often reluctant to reveal the true motives of their emigration, the children are much more comfortable with it. The young late resettlers under study believe that their parents invoked to their actual German roots, simply because there was no other possibility to leave Poland at that time. They do not feel obliged to prove their loyalty either to Germany or Poland. A huge contrast between 
living conditions in both countries made up for certain inconveniences, making their motivation stronger and their approach towards integration more favourable. They describe their adjustment as a kind of an automatic process, with both their present situation and the "(quasi)-forced nature" of their migration being taken for granted and not requiring further reflection. They look upon the combination of Polish and German culture elements as a positive asset.

\section{Bibliography}

Burszta W. J., Serwański J. (eds.) (2003), Migracja - Europa - Polska, PAN Zakład Badań Narodowościowych / Wydawnictwo Naukowe INPiD UAM, Poznań.

Dietz B. (1997), Jugendliche Aussiedler. Ausreise, Aufnahme, Integration, Berlin Verlag Arno Spitz Gmbh, Berlin.

Grabe W. (2000), Górnoślascy "przesiedleńcy"; w Niemczech, [in:] Wolff-Powęska A., Schulz E. (eds.), Być Polakiem w Niemczech, Instytut Zachodni, Poznań.

Graudenz I., Römhild R. (eds.) (1996), Forschungsfeld Aussiedler. Ansichten aus Deutschland, Peterlang - Europäischer Verlag der Wissenschaften, Frankfurt am Main.

Graudenz I., Römhild R. (1996), Grenzerfahrungen. Deutschstämmige aus Polen und der ehemaligen Sowjetunion im Vergleich, [in:] Graudenz I., Römhild R. (eds.), Forschungsfeld Aussiedler. Ansichten aus Deutschland, Peterlang - Europäischer Verlag der Wissenschaften, Frankfurt am Main.

Kaczmarek T., Edin-Kroll M. (eds.) (2006), Polen und Deutschland. Von Nachbarschaft zu Partnerschaft. Interdisziplinäre Beiträge von der 1. Polnisch-Deutschen SommerAkademie in Ciążen. 9.07.2006-15.07.2006, Bogucki Wydawnictwo Naukowe, Poznań.

Kłoskowska A. (1996), Kultury narodowe u korzeni, PWN, Warszawa.

Kunschner F. (2000), Zwischen zwei politischen Kulturen: Aussiedler in Bundesrepublik Deutschland, Deutsch-Russisches Zentrum, Leipzig.

Leoński J., Wątróbski L. (eds.) (2006), Diaspora: Polska tożsamość na emigracji, Vol. 2, Ośrodek Studiów i Badań Polonijnych Uniwersytetu Szczecińskiego, Szczecin.

Lüttinger P. (1989), Integration der Vertriebenen. Eine empirische Analyse, Campus, Frankfurt am Main. 
Mecheril P. (1997) Zugehörigkeitserfahrungen von Anderen Deutschen. Eine Empirische Modellierung, [in:] Pries L. (ed.), Transnationale Migration, Nomos Verlagsgesellschaft, Baden-Baden.

Meister D.M. (1997), Zwischenwelten der Migration. Biographische Übergänge jugendlicher Aussiedler aus Polen. Jugendforschung, Juventa Verlag, Weinheim und München.

Pallaske Ch. (2002), Migrationen aus Polen in die Bundesrepublik Deutschland in den 1980er Jahren. Migrationsverläufe und Eingliederungsprozesse in sozialgeschichtlicher Perspektive, Waxmann, Münster/New York, München/Berlin.

Pries L. (ed.) (1997), Transnationale Migration, Nomos Verlagsgesellschaft, Baden-Baden.

Schmidt J. (2003), W poszukiwaniu tożsamości. "Późni resettlers” z Polski lat 80. i 90. XX wieku w Niemczech, [in:] Burszta W. J., Serwański J. (eds.), Migracja - Europa Polska, PAN Zakład Badań Narodowościowych / Wydawnictwo Naukowe INPiD UAM, Poznań.

Tomaszewska M. (2006a), Identyfikacja narodowa młodych "późnych wysiedleńców" $z$ Polski w Niemczech, "Przegląd Zachodni" 2.

Tomaszewska M. (2006b), Język a typy identyfikacji narodowej młodych "późnych wysiedleńców“ z Polski, [in:] Leoński J., Wątróbski L. (eds.), Diaspora: Polska tożsamość na emigracji, Vol. 2, Ośrodek Studiów i Badań Polonijnych Uniwersytetu Szczecińskiego, Szczecin.

Tomaszewska M. (2006c), Wer bin ich? Nationale Selbsidentifizierung jugendlicher (Spät)Aussiedler aus Polen, [in:] Kaczmarek T., Edin-Kroll M. (eds.), Polen und Deutschland. Von Nachbarschaft zu Partnerschaft. Interdisziplinäre Beiträge von der 1. Polnisch-Deutschen Sommer-Akademie in Ciążeń. 9.07.2006-15.07.2006, Bogucki Wydawnictwo Naukowe, Poznań.

Tomaszewska M. (2006d), Jugendliche (Spät)Aussiedler aus Polen. Fremde oder Bindeglied zwischen Polen und Deutschland?, [in:] Ziółek M., Tomaszewska M. (eds.), Polen und Deutschland. Zusammenleben und -wirken. Interdisziplinäre Workshop-Berichte und Ergebnisse der 1. Polnisch-Deutschen Sommer-Akademie in Ciążeń. 9.07.200615.07.2006, Bogucki Wydawnictwo Naukowe, Poznań.

Uilhlein H. (2002), Migration und Integration in Deutschland, "Info-Dienst Deutsche Aussiedler" 114 
Wilkiewicz L.A. (1989), Aussiedlerschicksal: Migration und familiärer Wandel; dargestellt am Beispiel russlanddeutscher Familien in der Bundesrepublik Deutschland, Centaurus-Verlag, Freiburg.

Wolff-Powęska A., Schulz E. (eds.) (2000), Być Polakiem w Niemczech, Instytut Zachodni, Poznań.

Ziółek M., Tomaszewska M. (eds.) (2006), Polen und Deutschland. Zusammenleben und wirken. Interdisziplinäre Workshop-Berichte und Ergebnisse der 1. PolnischDeutschen Sommer-Akademie in Ciążeń. 9.07.2006-15.07.2006, Bogucki Wydawnictwo Naukowe, Poznań. 